\title{
Drikk kaffe med god samvittighet
}

\section{Kaffe er ikke assosiert med høyere risiko for død hos ikke-røykere.}

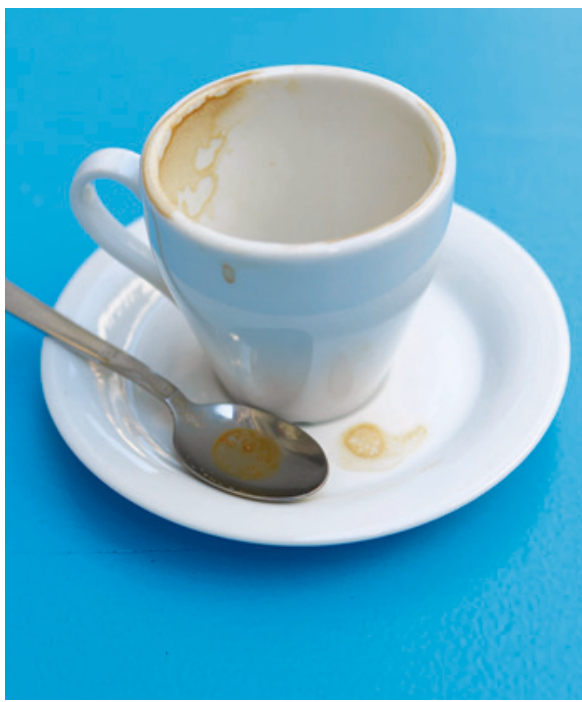

Illustrasjonsfoto: Thinkstock
Nordmenn ligger på verdenstoppen i kaffekonsum. Representerer det et folkehelseproblem? Det finnes mange studier der man har undersøkt om kaffedrikking fører til høyere mortalitet, og i flere observasjonsstudier er det konkludert med et inverst forhold mellom kaffeinntak og totaldødelighet.

I en stor studie som nylig er publisert i tidsskriftet Circulation ble data fra tre observasjonsstudier inkludert - med 208000 personer, rundt 4,7 millioner personår og rundt 32000 dødsfall (1). Inntaket av kaffe, både med og uten koffein, var ikke-linært korrelert til mortalitet. Sammenliknet med dem som ikke drakk kaffe førte konsum av 1-5 kopper kaffe om dagen til lavere mortalitet, mens de som drakk mer enn fem kopper, ikke hadde økt mortalitet. Når kun ikke-røykere ble tatt med, var assosiasjonen invers og linær.

- Denne studien bekrefter tidligere undersøkelser som viser at kaffe ikke er assosiert med høyere risiko for død hos ikke-røykere, sier Dag Thelle, som er professor emeritus i epidemiologi ved Universitetet i Oslo. - Dette skyldes først og fremst lavere dødelighet av hjerte- og karsykdom, men også av nevrologisk sykdom og selvmord hos kaffedrikkere, sier han.

- Studien er stor og vel gjennomført, og det er kontrollert for røyking og alkoholforbruk. Den ikke-linære sammenhengen mellom kaffe og dødelighet i totalpopulasjonen ble linær og invers når man avgrenset analysen til ikke-røykere, noe som tyder på at røyking er en konfunderende faktor. Én innvending mot studien er at den primært omfatter friske amerikanere i helse- og omsorgsyrker og at den derfor kanskje ikke er generaliserbar til hele befolkningen, sier Thelle.

- Observasjonsstudier kan påvise assosiasjoner og sammenhenger, men noe bevis $\mathrm{i}$ form av et randomisert intervensjonsfors $ø \mathrm{k}$ får vi aldri når det gjelder kaffe, avslutter han.

\section{Ketil Slagstad}

Tidsskriftet

\section{Litteratur}

1. Ding M, Satija A, Bhupathiraju SN et al. Association of Coffee Consumption with Total and CauseSpecific Mortality in Three Large Prospective Cohorts. Circulation 2015. E-publisert 16.11.

\section{Demens påvirker humoren}

\section{Pasienter med demens viser tidlig under sykdommen endret sans for humor.}

Humor er en sentral menneskelig egenskap og et viktig sosialt glidemiddel, men humor hos pasienter med demens er lite studert.

I en ny studie har man forsøkt å belyse sammenhengen mellom endret sans for humor og demenssykdom (1). Dette ble vurdert ved hjelp av et spørreskjema hos en gruppe pasienter med demens $(n=48)$ og en kontrollgruppe med friske $(n=21)$. For de syke var det en nær bekjent som besvarte spørsmålene. Humor ble klassifisert i tre grupper: slapstick (Mr. Bean), satirisk (Yes, Minister) og absurd (Monty Python). Det ble spurt om sans for humor i dag og 15 år tidligere.

Det viste seg å være særlig uttalt endret sans for humor hos pasienter med frontotemporallappsdemens. For alle demenstyper var det særlig sansen for absurd og satirisk humor som var mindre, mens det ikke var noen forskjell mellom gruppene når det gjaldt slapstick.

- Resultatene av denne studien samsvarer godt med mine kliniske erfaringer, sier Knut

\section{Litteratur \\ 1. Clark CN, Nicholas JM, Gordon E et al. Altered Sense of Humor in Dementia. J Alzheimers Dis 2015; 49: 111-9.}

Engedal, som er professor emeritus ved Geriatrisk avdeling, Oslo universitetssykehus. - Men studien har likevel flere svakheter. Dette er primært en tverrsnittsstudie, og antall pasienter er lite. I tillegg er det en tredjeperson som svarer på spørsmålene for den syke, og i begge grupper har man problemet med hukommelsesforskyvning. Imidlertid var pasientene svært godt utredet på forhånd, sier han.

- Helsepersonell og pårørende bør være seg bevisst at pasienter med demens ofte har endret sans for humor. Man bør få kartlagt sosial kognisjon hos pasienten, fordi det kan ha betydning for de råd man gir til pårørende og omsorgspersonell, sier han.

\section{Ketil Slagstad}

Tidsskriftet

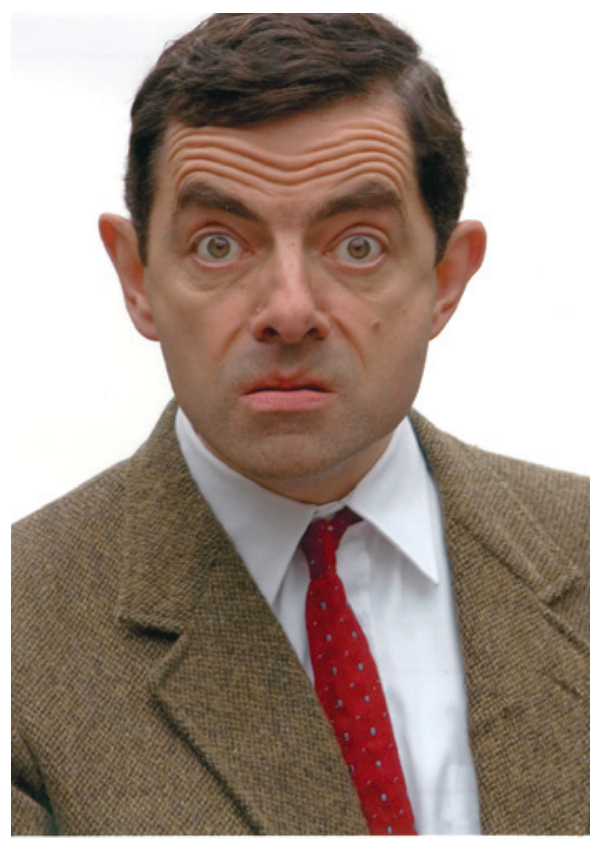

Illustrasjonsfoto: NTB scanpix 